Konstruktivisme : Jurnal Pendidikan dan Pembelajaran

Vol. 11, No. 02, Juli, 2019, e-ISSN: 2442-2355

FKIP, Universitas Islam Balitar

Website: https://ejournal.unisbablitar.ac.id/index.php/konstruktivisme/index

Email: konstruktivisme@unisbablitar.ac.id

\title{
IMPROVING STUDENTS' VOCABULARY ACHIEVEMENT USING VOCABULARY CHARTS TECHNIQUE
}

\author{
Winarsih ${ }^{(1)}$ \\ English Education Department, Faculty of Teacher Training and Education \\ Universitas Islam Balitar Blitar \\ JI. Majapahit No. 04 Blitar \\ E-mail:winponti96@gmail.com
}

\section{ABSTRACT:}

This article investigates the technique of teaching vocabulary using Beare's vocabulary charts. The technique helps to improve students' mastery of English language and widens their passive and active vocabulary based on related word group areas. The relevancy between vocabularies in the charts is the vocabulary used in students' daily activities. Adopting a Classroom Action Research, this study collected the data by using vocabulary charts, tests, field notes, checklist, and questionnaires. The result showed that the implementation of vocabulary chart has improved semester three students' vocabulary achievement at Universitas Islam Balitar, Blitar. $77 \%$ of the students passed the minimum criteria of success in the first cycle, and $75 \%$ of the students passed the minimum criteria in the second cycle. This technique is beneficial to facilitate students in learning English vocabulary. Vocabulary word charts in teaching English vocabulary are thus recommended.

Keywords: Vocabulary Charts, Technique, English Vocabulary 
Winarsih(1) 2019. Improving Students' Vocabulary Achievement Using Vocabulary Charts

Technique.

Konstruktivisme : Jurnal Pendidikan dan Pembelajaran, 11 (2): 123-128

\section{ABSTRAK:}

Artikel ini menjelaskan teknik pembelajaran vocabulary dengan menggunakan Beare's vocabulary charts. Teknik ini berguna untuk meningkatkan penguasaan kosakata siswa serta menambah perbendaharaan kata baik kata aktif maupun pasif. Kosakata yang berada dalam charts adalah kosakata yang umum digunakan dalam kegiatan sehari-hari. Dengan menggunakan jenis Penelitinan Tindakan Kelas, penelitian ini menggunakan beberapa instrument seperti vocabulary charts, tes, catatan lapangan, ceklis, dan kuesioner. Hasil penelitian menunjukkan bahwa penerapan vocabulary chart meningkatkan penguasaan kosakata mahasiswa semester tiga Universitas Islam Balitar. 77\% siswa mencapai KKM di siklus pertama, dan $75 \%$ siswa juga mencapai KKM di siklus kedua. Teknik vocabulary charts bermanfaat untuk membantu siswa mempelajari kosakata. Teknik ini dianjurkan untuk dipakai pada pembelajaran kosakata

Kata Kunci: Vocabulary Charts, Teknik, Kosakata

\section{INTRODUCTION}

English is not merely the first language, but people use English as a second and foreign language. According Harmer (2005: 1), English has become a lingua franca. English is widely adopted for communication between two speakers whose native language is different from each other. Thus, they use English as second language. Most people who learn the language have compelling and urgent reasons for doing so (Handly, 2005: 2) Nowadays, English is used for business, politics, and social reasons.

English is very popular in Indonesia as a medium of instruction in some schools. Moreover, it also has been spoken in higher social level. The urgency of English makes Vocabulary charts can be very useful in helping students widen their passive and active vocabulary based on related word group areas. For example, a small group of students create vocabulary chart based on a given word "The city"; with this "hook" word the students are given the particular word in connected categories with a set of words shops, buildings, people, transport, etc. Then, for the connected word of shops, students reconnect with words: butcher, baker, grocer, supermarket, department store, etc. (http://esl.about.com). It helps to improve students' achievement in vocabulary use of English speaking, writing, reading, and listening.

Davis in Harmer says, "Such a program will make students more positive about reading, improve their overall comprehension skills, and give 
them a wider passive and active vocabulary" (2005: 204). Wilkins in Budiharso states that vocabulary is important not only for learning a language itself but also for the language in communication. Without grammar, very little can be conveyed, but without vocabulary, nothing can be conveyed (2004:93). Teaching vocabulary is a major part of teaching English. Students need to see how vocabularies are used accordingly. The best way of introducing new words to students is to read texts or listen to audio tracks and see or hear those words in action (Harmer, 2007: 235).

The aim of teaching English as a foreign language in Indonesia is to provide students with the ability to use target language for communication. It is used as a medium of instruction in some schools, and spoken in higher social level. Moreover, children in playgroups, kindergarten, and elementary school learn and play with English at the beginner level. Harmer (2005: 37), children of primary age acquire much of a foreign language through play.

By learning vocabulary, students certainly know quite a lot about new words they have been learning. According to Harmer (2007: 229), the instructors start by showing or drawing pictures, or miming the actions the words are carefully modeled, conducting a rapid cue-response drill where instructors point to a picture, or miming the action and nominating a student to say, walk, climb, etc. The students are now asked to put the correct verb in the sentences. These can be projected or written onto the board, provided that the students can still see the pictures. This can be done with the whole class or the students can work in pairs. If the students have worked on the exercise in pairs, the instructor now goes through the answers, making sure that the student pronouns the words correctly.

The aim of the activity is either to have students use words that they more or less know, but they need to be provoked into using, or get them to think about word meaning, especially in context. Students should by now have begun to get the idea (even if they haven't done a word map before this), but just to be sure, we elicit words for one of the rooms, such as; the kitchen (cooker, fridge, frying pan, and sink).

Once the words chart is complete or full as it is likely to be, the instructor can make sure the students can say the words correctly. Before going on to ask them to describe their favorite room at home or have a discussion about why people don't put television in the bathroom or fridges in the bedroom, we can give students a picture or plan an empty room and ask them to decide what to put in it. According to Harmer, words map are sometimes used by instructors to show students words group together. Getting students to build up their own map by working in groups (as we have suggested) has the added advantage of making them try to remember some of the many words they know, while at the same time learning new words from their peers (2007: 8 \& 236). 
Winarsih(1) 2019. Improving Students' Vocabulary Achievement Using Vocabulary Charts

Technique.

Konstruktivisme : Jurnal Pendidikan dan Pembelajaran, 11 (2): 123-128

\section{METHOD}

This research adopted a Classroom Action Research (Kemmis, S., 1998) that was carried out in two cycles. This study engaged the third semester students of Universitas Islam Balitar, enrolled in English Education Department. To collect the data, the researcher used two kinds of vocabulary charts in two cycles. There were example vocabulary chart and the idea of creating vocabulary charts. At the first cycle, both of them were presented and implemented by the instructor 'researcher' then the students practiced - with two groups' class competition - on the whiteboard. Meanwhile, at the second cycles, students created vocabulary charts in pairs based on a particular subject area. Before implementing the first cycle, the researcher administered a pretest. Each cycle consisted of teaching learning process of vocabulary charts and test. At the end of each cycle, a posttest was administered. The result of posttests were then analyzed whether it exceeded the criteria of success, that is, the students got the score at least 69 .

\section{RESULT}

The average score of the achievement in first cycle was 77. According to the criteria of success provided by school, which was earlier informed by the English instructor, obtaining the score of 69 was said to be successful. Therefore, it concluded that the first cycle was successful. The average achievement of the students in the second cycle was 75 . According to the criteria stated in the previous chapter, it could be said that this activity was successful.

In the first cycle, the researcher taught and gave vocabulary chart practices through class discussion and competition. Meanwhile, in second cycle instructor changed her technique of teaching by asking students working in pairs. It gave a significant result to the both achievement in first post-test of the mean score at 77 , and 75 in the second post-test. The scores were the highest rate compared the achievement of pre-test score at the mean of 59 under the criteria of success at 69 . Figure 1 shows the students' scores. 
7.1 The Frequency of Test Scores

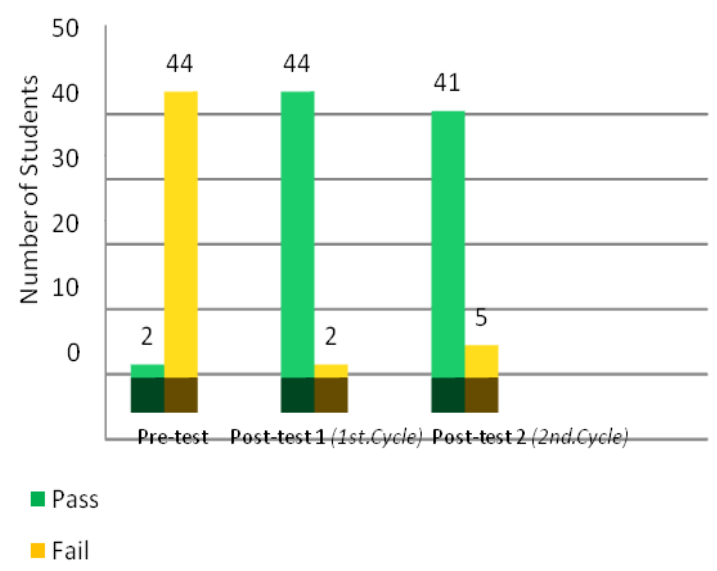

Figure 1 : The Students' Score in Pre-test and Post-tests

Figure 1 shows the comparison of students' achievement on vocabulary tests between pre-test to post-test 1 and 2 . There were 2 of 31 students pass on pre-test and scored $>70$. The rest of 44 students scored $<69$. However, after students had received treatment to improve vocabulary mastery using charts, about 44 students (in first cycle) and 41 students (in second cycle) achieved a significant improvement in the tests at the scores $>70$ to the minimum criteria of success, the Mean score in post-test 1 at 77 and post-test 2 at 75.

The observation took place during teaching learning activity and the English instructor had been collaborated being the observer in the classroom. He observed and wrote down the process on a checklist. After the treatment with vocabulary chart, the researcher gave students a test to find the students' vocabulary achievement. The result would be comparing to the criteria of success.

\section{DISCUSSION}

The findings revealed that vocabulary charts improved students' vocabulary mastery. When the researcher showed the vocabulary chart for the very first time, some students showed their enthusiasm and directly asked wanted to know. By chance, the practice and study of vocabulary chart was conducted close to the students' final test for senior high school. It gave a hope to them to have the opportunity to study extra hard for final test.

During the treatment of the first and second cycles, most of students raised their hands and answered enthusiastically whenever the instructor asked questions that were related to the 'hook' words. However, instructor 
Winarsih(1) 2019. Improving Students' Vocabulary Achievement Using Vocabulary Charts Technique.

Konstruktivisme : Jurnal Pendidikan dan Pembelajaran, 11 (2): 123-128

sometimes ordered to encourage the students to whom did not give much attention to answer the questions in order to catch their interests.

\section{CONCLUSION AND SUGGESTION}

Students are able to improve their useful vocabulary in four skills of writing, reading, speaking, and listening that the language has. Meanwhile, the students know what the problem within learning. The use of vocabulary charts should be maintained frequently and thus highly recommended for teaching vocabulary.

\section{BIBLIOGRAPHY}

Bear, K. (2011). Http://.about.com ...accessed on April 5, 2011

Budiharso, T. (2004). Prinsip dan Strategi Pengajaran Bahasa, Surabaya: Lutfansa Mediatama.

Handly, B. (2005). Fast Easy Way to Learn a Language, Australia: Graffin Press.

Harmer, J. (1998). How to Teach English. New York: Longman Group 